\title{
Multimedia-Based Computer Network Media Applications
}

\author{
Syuryadi $^{1}$, Nurkhalik Wahdanial Asbara ${ }^{* 2}$, Nurani ${ }^{3}$ \\ ${ }_{1,2,3}$ Institut Teknologi dan Bisnis Nobel Indonesia Makassar
}

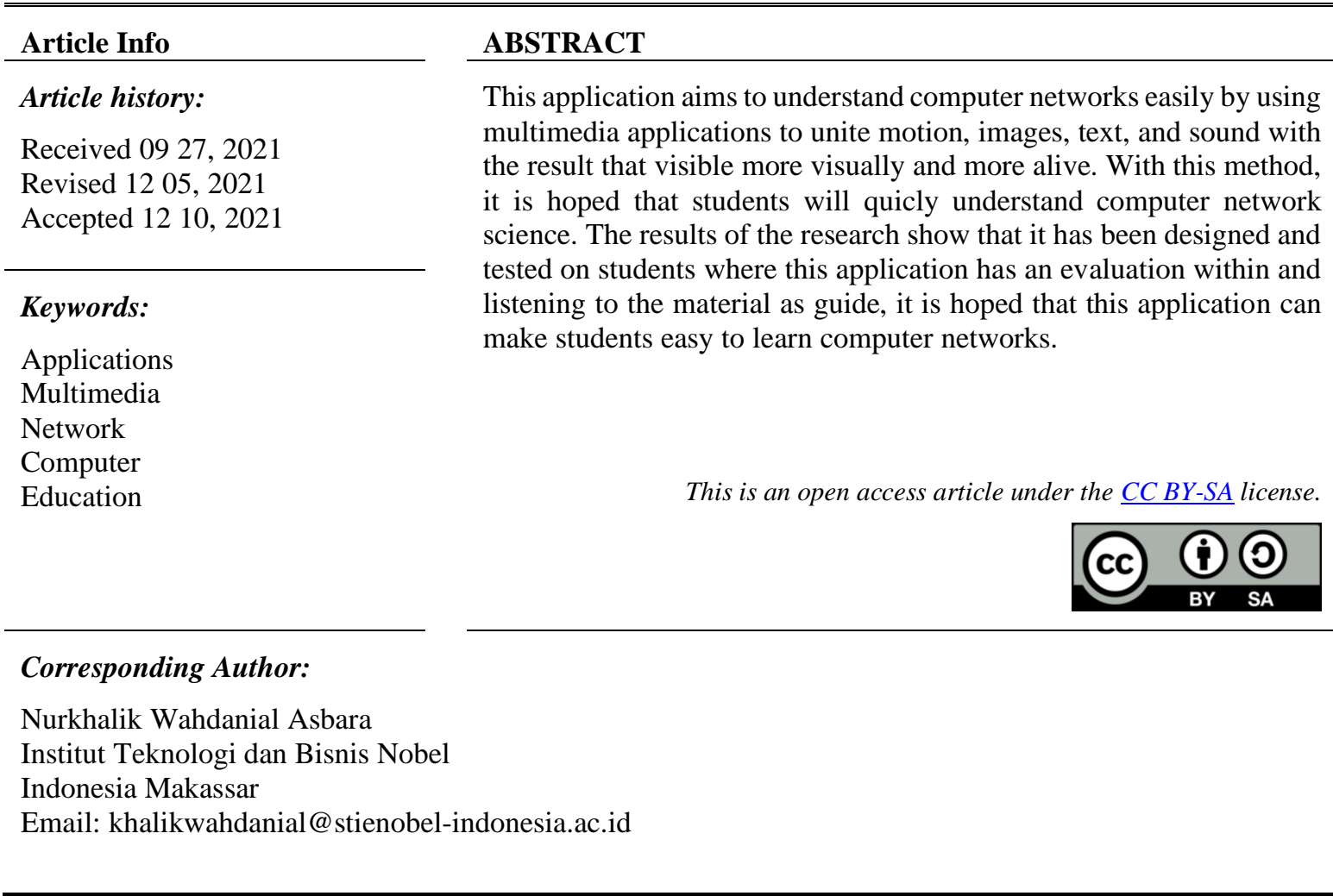

\section{Introduction}

Education is a universal activity in human activities, because wherever and whenever there is an educational process [1]. With a touch of learning technology that using audio visuals it will attract more attention to respond than using books and blackboards.

Education is educative game containing educational elements were designed and created to stimulate thinking, train and solve problem evaluations, optimize activities so that interaction between students and teachers, ability development, and adaptation are needed to providing the ability to take responsibility for obtaining good character in the future.

The old system using notebooks as student handbook, with this method of learning, there are still many lack faced by students, for example, if a teacher cannot attend to the class and cannot teach as usual, it is rare and even there was never a teacher who directly replaced his position to teach.

The problem in this research is formulated that how to design applications for schools using multimedia-based computer network media and how to implement applications for schools using multimediabased computer network media.

Students who are given formal or informal responsibilities can apply them in their daily lives, namely how students can recognize and understand multimedia-based computer network science so that students can be creative, interact, in the learning and teaching process was given by teachers. 
This multimedia-based computer network media application is a medium as a method where teachers and students more interactive in the teaching and learning process, a new way to guide students easily and quickly understand of this multimedia-based computer network science.

\section{Literature Review}

System

The system comes from Latin "systema" and from Greek "sustema". It means a unit of components or elements are connected together to facilitate the flow of information, material or energy.

The different definition of system in various fields, but all systems have some general requirements must be include within. For example in a system must have elements, environment, interaction between elements, interaction between elements and their environment. One of the most important indicators is the system must have a goal to be achieved.

According to [2] the system is a network of interconnected procedures, gathered together to carry out an activity or to complete a certain goal. According to [3], the system is a network of interconnected elements that form a unit to carry out a main purpose of the system. The system is a network of interconnected elements that form a unit to carry out a main purpose of the system.

According to [2] the system is a network of interconnected procedures, gathered together to carry out an activity or to complete a certain goal. According to [3], the system is a network of interconnected elements that form a unit to carry out a main purpose of the system. The system is a network of interconnected elements that form a unit to carry out a main purpose of the system.

\section{System Characteristics}

The general model of system consists of input, process, and output. This is a very simple concept of a system has several inputs and outputs at once. In addition, a system also has certain characteristics or properties. The characteristics of system are as follows [4] :
a. Components System
b. Boundary System
c. Environtment System
d. Interface System
e. Input System
f. Output System
g. Procces System
h. Objective System

\section{System Design}

According to [5] stated that Design is a process to define something to be done using various techniques within involves description of the architecture and detail components and also the limitations that will be experienced in the process.

System design is an activity carried out to design a system that has work stages that are logically arranged, starting from collecting the data needed for the implementation of the design.

\section{Perancangan Sistem}

According to [5] stated that Design is a process to define something to be done using various techniques within involves description of the architecture and detail components and also the limitations that will be experienced in the process.

System design is an activity carried out to design a system with logically arranged steps, starting from data collection needed for design implementation.

\section{Application}

Based on [6] Aplication is created software by computer company to do certain tasks such as MsWord, Ms-Excel, Photoshop. The size of a RAM affects the process of running applications.

Applications are computer software that functions to process an order from user with a specific purpose. Application software consists of:

1. Programming Language

2. Application Program

3. Packet Program

4. Utility Program

5. Games and Entertainment, etc. 

into:

According to [7] in running the application software above, the tasks of computer users are divided

a. System Analyst

b. Programmer

c. Operator

d. Database Administrator, is the person who processes and manipulates database software. If the software to be operated uses database application, this user is needed.

e. Network Administrator, is the person to manage the network of system.

\section{Multimedia}

Based on [8] in general, multimedia is defined as a combination of text, images, graphic art, animation, sound and video. Multimedia is only a tool can be used by the teacher to liven up the process of learning atmosphere [9]. The four important components of multimedia are:

1. There must be computer to coordinates the interaction.

2. There must be link to connects with the information.

3. There must be navigation tool to guides, to explore the interconnected network of information.

4. Multimedia provides a place for us to collect, to process and to communicate of information and ideas.

The types of Multimedia designs according to [10] are :

1. Interactive Multimedia

It is multimedia product where user can operate through the navigation provided by using a mouse, keyboard or other input device. Some examples of this type are: Game Applications, Interactive CDs, virtual reality, application programs and so on.

2. Linear Multimedia

It is multimedia product where running structure runs straight and cannot be controlled by the user. This type is common in society, some examples are television broadcasts, films, music and etc.

3. Hyperactive Multimedia

It is multimedia product has more complex navigation controls, so the users can operate it more freely than interactive multimedia types. Examples of this type oare Websites and Online Games.

4. Kits Multimedia

It is multimedia product consisting of several types of media and packaged in one topic. So, be able to operate it requires other devices besides computer. For example CD Room, Audio cassette, overhead transparency, static images and etc.

\section{Multimedia Serving Format}

The format of the learning multimedia presentation can be categorized into five groups as follows:

1. Tutorial, this format is learning multimedia to deliver material in tutorial, i.e. tutorial was conducted by teacher or instructor. Information contains concept with text, images, sticker and graphics. At the correct time, i.e. when it is considered that user has read, interpreted and absorbed the concept, the questions or tasks are asked. If the answer or user response is correct, then process can continue to the next material. If the user's answer or response is wrong, the user must repeat the understanding of the concept (remedial). Then at the end, the questions will be given to measure the level of user understanding of the concept or material presented.

2. Drill and Practice, this format is intended to train user to have proficiency in a skill or strengthen mastery of concept. The program provides the questions randomly, it means the questions displays are always different, or at least in different combinations. This program is equipped with correct answers, complete with explanations so that it is hoped users will be able to understand a certain concept. At the end, the user can see the final score, as an indicator to measure the level of success in solving the questions posed.

3. Simulation, Multimedia learning with this format tries to match the dynamic processes that occur in the real world, for example to simulate an airplane, where the user seems to be carrying out activities to fly an airplane, run a small business, or control a nuclear power plant, etc.

4. Experiment, this format is similar with simulation format, but it aimed at experimental activities naturally, such as practicum activities in science, biology or chemistry laboratories. The program provides set of tools and materials, then the user can carry out experiments according to the instructions and then develop other experiments based on these instructions. It is hoped that in the end users can explain a certain concept or phenomenon based on the experiments virtually.

5. Games, the form of games presented refers to the learning process and with this format multimedia program, it is hoped that learning activities while playing will occur. Thus users do not feel that they are actually learning. 


\section{Multimedia Applications in Education}

Educational multimedia applications come in many forms and approaches. There are educational multimedia applications provide information or focus more on specific topics. There are educational multimedia applications are produced for general use and some are produced for certain groups only. It is undeniable that multimedia technology is able to make a big impression in the field of communication and education because it can integrate text, graphics, animation, audio and video. Multimedia has developed the teaching and learning process in more dynamic. The use of multimedia in the educational process should indeed be implemented, because it will further improve the quality of the results of the educational process [11].

\section{Computer network}

Network is an operating system consist of a number of computers and other network devices to achieve a common goal or network which consist of points (nodes) are connected to each other, with or without cable. Each node serves as workstation. One of the nodes as a service media or server, which regulates functions of other nodes. Basically, computer network technology is combination of computer technology and communication technology

Computer network is a system consist of computers designed to be able share resources (printers, CPUs), communicate (e-mail, instant messages), and be able to access information (web browsers). The purpose of computer network is to achieve its goals, every part of computer network can request and provide services [12].

\section{Results and Discussions}

\section{Use Case Diagram Design}

Use Case Diagram is a technique for recording the functional requirements of a system. Use Case Diagrams describe typical interactions between system users and the system itself, for more details the design of the system can be seen in the image below:

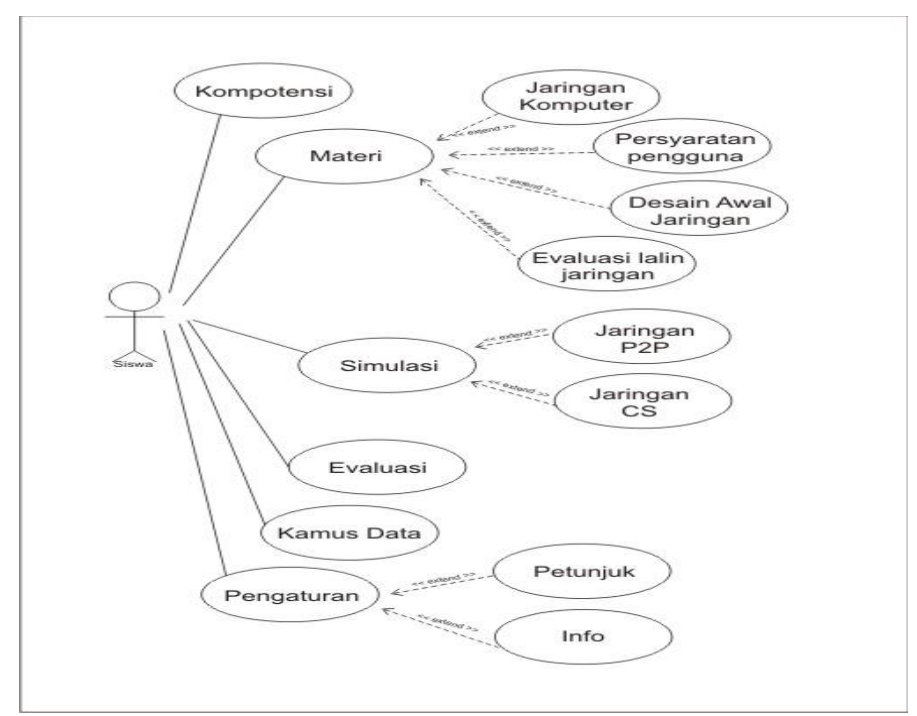

Figure 1. Use Case Diagram

In this case there is 1 actor in use case diagram, it is the student as the user. Users can easily use this application has been specially designed for computer network-based multi-media learning where there are various kinds of modules and options for both material, competence, simulation, evaluation include in one application about educational computer network learning based on multimedia of computer networks to apply and implement directly by the students in one learning package.

\section{Proposed System}

In this research, Multimedia Learning system will be designed as solution to overcome the lack and the weaknesses of the previous system. It is learning system, it can be accessed by students for learning media, especially computer network learning. The following is form of proposed system: 


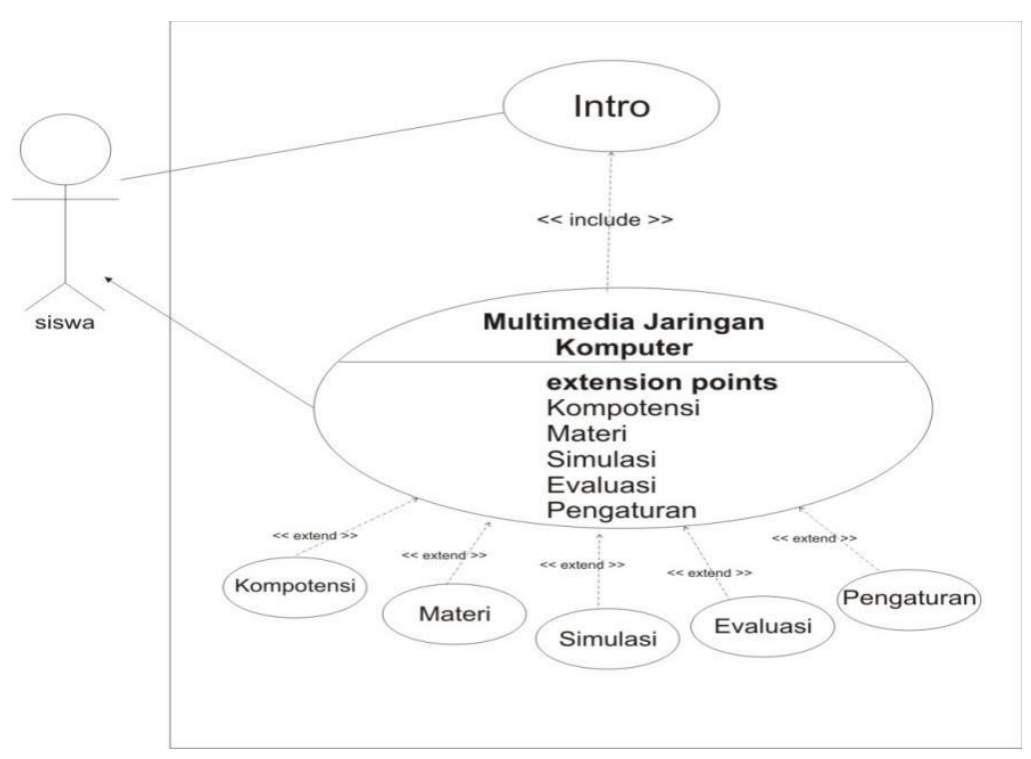

Figure 2. Proposed System

In this case there is one actor, it is the students (users) and there are various kinds of modules that are specifically related to learning computer networks consist of self-development competence material regarding LAN, MAN and WAN networks, while the options for these materials include:

- Computer network learning

- User requirements

- Initial network design

- Evaluation of network traffic

The option of simulation material studies:

- Types of network types such as P2P (peer to peer) networks

- CS network (client server) etc

The data dictionary is summary of terms commonly used in networks such as:

- ADN (advanced digital network)

- ADSL (asymmetric digital subscriber line)

- Bandwidth is how much data is passed in a connection through a network, etc.

In the settings menu, there is info and instructions for user and procedures for using the application and all of this can be accessed and studied by students including in a multimedia-based computer network learning package in educational.

\section{Implementation}

a. Loading Page Display

Explanation: This section will display when the application starts to run, and go to loading page, when the loading is complete, go directly to main menu. 


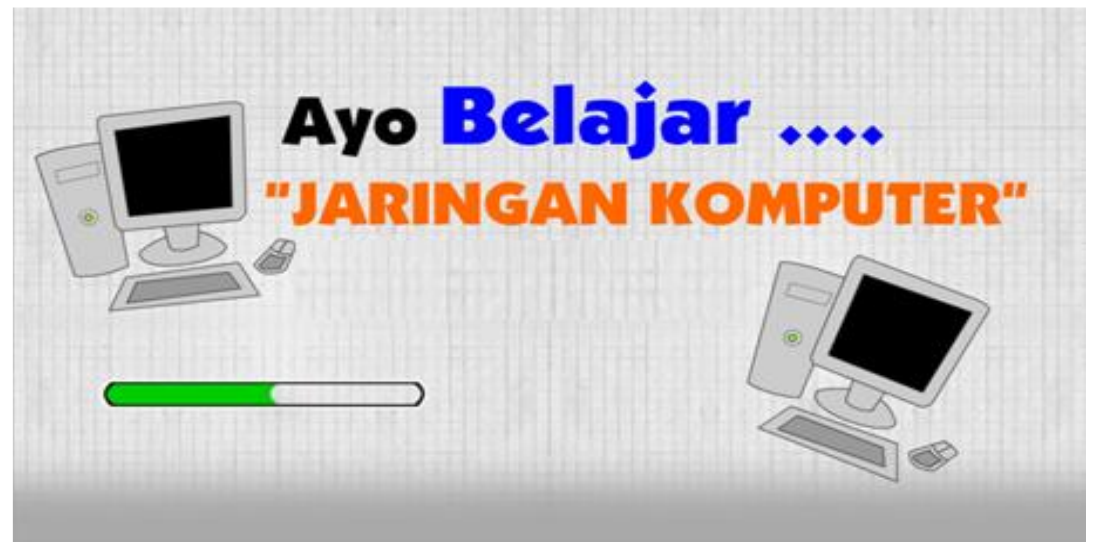

Figure 3 1.Loading Page Display

b. Menu Page Display

Explanation: This section will display when loading is complete. In this menu the user/student selects the available menu.

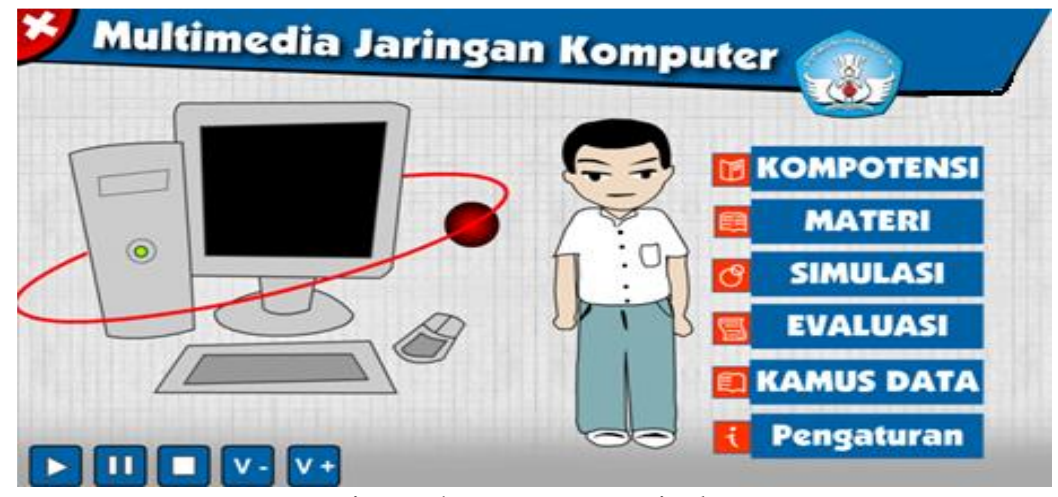

Figure 4. Menu Page Display

c. Competency Page Display

Explanation: The Competency Standards menu displays all competency standards of students after studying computer network material, Press the left and right arrow keys to view again

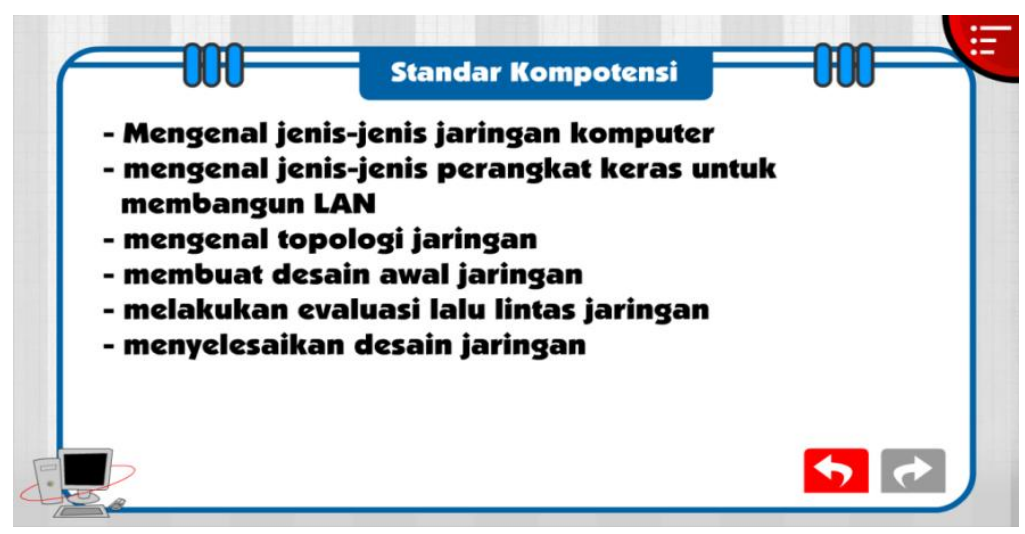

Figure 5. Competency Page Display

d. Material Page Display

Explanation: The Materials menu displays sub-materials from LAN network, Select the sub-menu to view learning materials. 


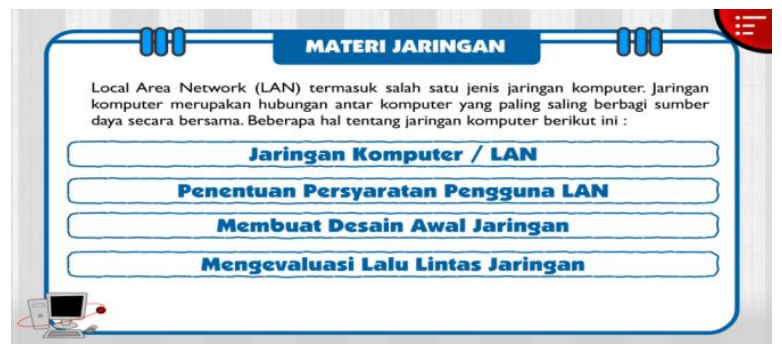

Figure 6. Material Page Display

e. Simulation Menu Display

Explanation: the simulation menu displays a peer to peer and client server network simulation, Select a simulation image to simulate the network.

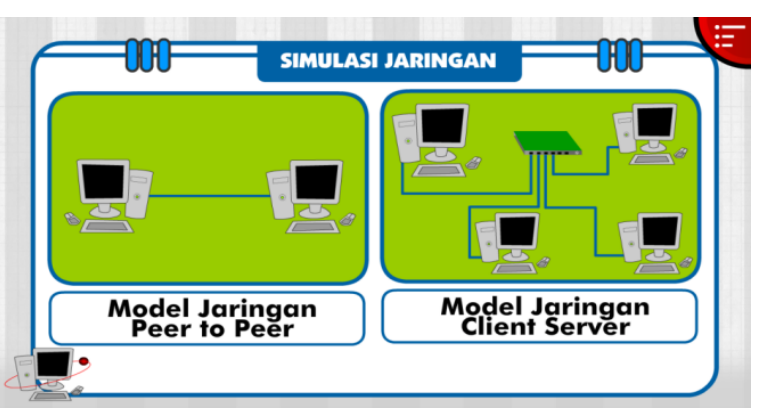

Figure 7. Simulation Menu Display

f. Evaluation Menu Display

Explanation: the evaluation menu displays questions from the material, enter name and press the "Start" button.

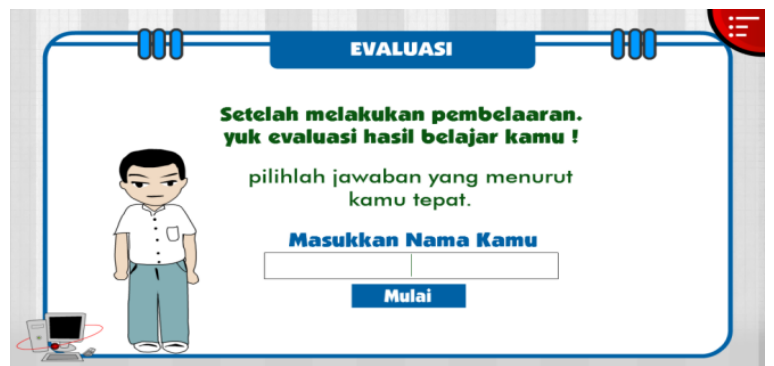

Figure 8. Evaluation Menu Display

g. Data Dictionary Menu Display

Explanation: The data dictionary menu displays the abbreviated data in the material menu. Click the scrollbar to move up and down the text.

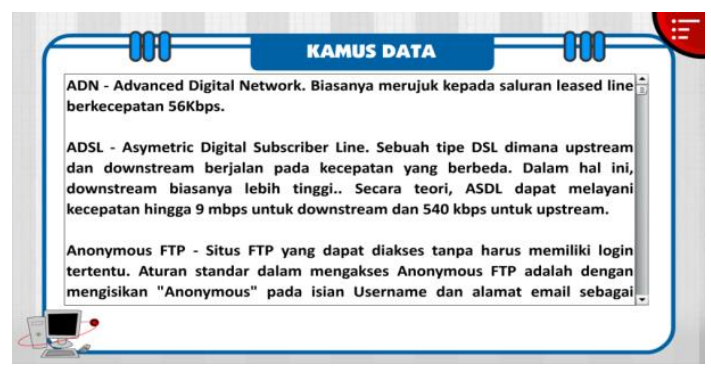

Figure 9. Data Dictionary Menu Display

h. Setting Menu Display

Explanation : Settings menu shows button instructions and application info, select a button to see the changes. 


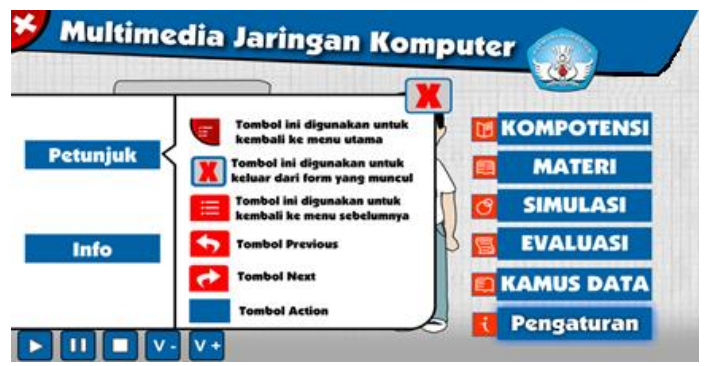

Figure 10. Setting Menu Display

\section{Conclusion}

Based on the descriptions and explanations above, the researcher can conclude that this application is standalone, not connected to network and does not use database. This application can be an alternative learning media to introduce computer network learning. As well as optimizing multimedia in the field of education. This application is easy to use by students, it looks attractive, the learning process becomes more fun, the intonation of the voice produced is easy for students to understand. This application can improve the learning process and people's motivation to learn Computer networks because it is equipped with simulation and evaluation, it also increases the tendency of children to start learning.

\section{References}

[1] M. Hasan, T. K. Harahap, S. Sos, and M. S. D. Inanna, Landasan pendidikan. Penerbit Tahta Media Group, 2013.

[2] H. M. Jogiyanto, "Sistem teknologi informasi," Andi. Yogyakarta, 2005.

[3] H. Nopriandi, "Perancangan sistem informasi registrasi mahasiswa," J. Teknol. Dan Open Source, vol. 1, no. 1, pp. 73-79, 2018.

[4] T. Sutabri, Analisis sistem informasi. Penerbit Andi, 2012.

[5] S. R. Wicaksono, Rekayasa Perangkat Lunak. Seribu Bintang, 2011.

[6] S. Satria, "Kamus Istilah Komputer," Yogyakarta Wahana Total. Publ., vol. 8, 2010.

[7] B. Nugroho, "Sistem Informasi Rekam Medis Di Puskesmas Masaran I Sragen." STMIK Sinar Nusantara Surakarta, 2014

[8] B. S. D. Oetomo, "E-education konsep, teknologi dan aplikasi internet pendidikan," Yogyakarta Andi, 2002.

[9] Y. Andinny and I. Lestari, "Pengaruh pembelajaran multimedia terhadap hasil belajar matematika," JKPM (Jurnal Kaji. Pendidik. Mat., vol. 1, no. 2, pp. 169-179, 2016.

[10] “Apa Itu Multimedia ? Berikut Pengertian dan Jenis - Jenisnya.” https://www.utopicomputers.com/apa-itumultimedia-berikut-pengertian-dan-jenis-jenisnya/ (accessed Sep. 23, 2021).

[11] M. Ramli, “Aplikasi Teknologi Multimedia dalam Pendidikan," Ittihad J. Kopertais Wil. XI Kalimantan, vol. 11, no. 19, pp. 55-65, 2013.

[12] M. J. N. Yudianto, “Jaringan komputer dan Pengertiannya," Ilmukomputer. Com, pp. 1-10, 2014. 